\title{
A Critical Humanist Intervention: Agency, Structure and Values
}

\author{
Vanesa Amaris \\ University of Tirana Tirana, Albania \\ Email: amaris.vane77@hotmail.com
}

\begin{abstract}
The main aim of the article is to suggest what and how a contemporary, revised version of humanism, inflected with critical realism and Marxism, can contribute to sociology. I focus primarily on two areas in which sociology is often found lacking today: theorizing the relationship between structure and agency, and deciding what to do with moral evaluations in sociological analyses. I argue that the solution to both lies in attempting to finally transcend the traditionally hostile and mutually exclusive paradigms of "humanist" or "cultural" Marxism on the one side and "anti-humanist" or "scientific" Marxism on the other. This enables us to carefully reinstate the agency of human subjects and the moral dimension, both of which were and still are dismissed by anti- or post-humanist social science, without neglecting the objective and causally relevant existence of social structures at the same time.
\end{abstract}

Keywords: Marxism, Humanism, Anti-Humanism, Subject, Structure.

\section{A. INTRODUCTION}

In the past few decades, Marxism and its flagship insistence on the importance of class have markedly declined in various fields of the humanities and social sciences, especially in the fields that have to do with the important issues of culture (Eley 2005; Chibber 2006). This is not to say that Marxism has been altogether absent from, say, cultural sociology and cultural studies. Indeed, the influence of a certain sort of Marxism, the infamous anti-humanist Marxism emerging out of the disintegration of the Althusserian School, drawing heavily on a particular interpretation of Antonio Gramsci and taking as its main inspiration the radical theses of Jacques Lacan, Michel Foucault or Jacques Derrida, has been very palpable especially in cultural studies (e.g. Laclau \& Mouffe 1985; Hall 1996).1 Such Marxism or, more appropriately, post-Marxism has contributed to the broad "post human orthodoxy that is still prevalent in the humanities and social sciences" (Chernilo 2016: 310) and has been well received because of this long-lasting orthodoxy. As Daniel Chernilo (Ibid.) states in a recent review of the literature: "From Levi-Strauss to Latour, via Althusser, Foucault and Luhmman, the critique of humanism has remained a major trope that resonates also with the various motifs of feminist, postcolonial, neo-Marxist, trans humanist and animal rights positions."

It is, therefore, surprising as well as refreshing that we are today, in the context of the thorough downplaying of class and salience of anti-humanism (or post humanism), hearing more and more explicit appeals for sociology in general and cultural sociology in particular to explore anew how a critical or revised humanism and, more to the point, humanist Marxism might contribute to contemporary 
debates (e.g. Chernilo 2016; Durkin 2014; Maher 2016; Porpora 2015; Sayer 2011; Stevenson 2016; also, from a non-Marxian viewpoint, Brereton 2011; Smith 2010). Such humanism or humanist Marxism, certainly not adopted uncritically, is said to be helpful especially in relation to the most urgent is-sues posed by today's truly global (and crisis-ridden) capitalism, the place and workings of culture it partly shapes, and the ever-present, if weak, resistance it inevitably provokes.

However, when discussing the potential Marxism in general or humanist Marxism in particular holds for contemporary sociology it is hard not to be reminded immediately of the decades-old and decades-long debates within Marxism on whether it should be concerned with facts or values, epistemic realism or conventionalism, "rigorous" scientific explanation or ethical critique, objective laws of motion or subjective experiences and consciousness, structure or agency, and so on. Indeed, the "Two Marxisms" of which Alvin Gouldner (1980) spoke can be traced back to Karl Marx himself, at least if one is willing to be a bit exegetically selective (on this, see the excellent work by Creaven 2015). It might seem, therefore, that this would be a fruitless rehashing of an old debate that has stalemated, a debate between the "cultural" or "humanist" Marxism of Georg Lukacs or E. P. Thompson on the one hand, and the "scientific", "anti-humanist" Marxism of Louis Althusser or Göran Therborn on the other. If this were true, the endeavour would almost certainly be pointless.

The issue is even more complicated because Marxism's cards were reshuffled in the 1980s. Two new influential versions of Marxism emerged out of the Althusserian wreck-age: rational-choice Marxism (RCM) and the already mentioned post-Marxism. Both of them were descendants of the Althusserian project, albeit in radically different ways. As a notable representative of RCM states:

[RCM] has inherited the mantle of Althusserian structuralism. But it is not the linear descendant of Althusserianism, since it seems to have developed in wholesale reaction against, rather than critical engagement with, the Althusserian legacy. I take post-Marxism to be precisely the linear descendant of Althusser at least in regard to the characteristic cluster of problems associated with the concept of ideology. (Carling, 1986: 55)

These two do not fit neatly within the traditional divide between "cultural" and "scientific" Marxism. For instance, post-Marxists (such as Laclau \& Mouffe) definitely embraced and even radicalized Althusser's "scientific" anti-humanism. They dismissed, as did Althusser, all of the allegedly "pre-scientific", ideological references to universal human nature or essence (i.e. people's fundamental needs and capabilities), their lived experiences or consciousness, and similar anthropological or psychobiological characteristics not wholly determined by social factors. Yet, in sharp contrast to Althusser, they also expunged from their antihumanist Marxism any notion of objective "laws of motion", the primacy of the economy, epistemic objectivity, the distinction between extra-discursive and discursive, and so on. ${ }^{2}$ RCM theorists (such as Alan Carling, Adam Przeworski, John Roemer or Jon Elster) went, to the contrary, to great length to situate themselves as 
objective, rigorous scientists utilizing the latest social-scientific techniques, such as game-theoretical models, psychological experiments, statistics, and so on. However, they emphasized, at the same time, the need to adopt methodological individualism as opposed to Althusserian holism, and to recognize the fact that a common human nature exists. They also developed or tried to develop, in contrast to the ostensibly scientific Althusserianism, sophisticated moral indictments of capitalism.

The aim of this article is to suggest there is a possibility of constructing a kind of "unitary" or, as I prefer, "critical-humanist" Marxism that combines the best insights of all the various prominent strands mentioned above, while rejecting the claims that have not withstood scholarly scrutiny. I will concern myself primarily with two dimensions of the proposed renewal: how to bridge the gap between the objective and the subjective or structure and subject, and how to take scientific note of the ostensibly extra-scientific value judgements.

\section{B. METHOD}

This research is qualitative in nature with a literature review method. Data were collected using several techniques, including observation, focus group discussion of documentation studies (Creswell, 2010). The data is then analyzed so that a conclusion can be made of the research results related to this research.

\section{RESULTS AND DISCUSSION}

\section{Structure and Subject: A Tortured Relationship}

When sociologists consider the relationship between individual people and the larger society there are usually at least two mutually exclusive but equally attractive thought-processes at work. One is to reduce everything social to the individual, both explanatorily as well as ontologically. Such methodological individualism is attractive because it seems, prima facie, absurd for social structures such as classes, states or the economy to really exist, i.e. to possess their own causal powers over and above those of their parts. The only reasonable thing to assume seems to be that it is only living individuals who possess causal powers; therefore, any talk of social structures is, at best, merely heuristic (e.g. Collins 1981: 988; Elster 1985: 4). "Class" or "the state" are terms that designate groups of people whose individual interactions are the product of those very people that is it. So, strictly speaking, classes or the state do not exist, at least not as anything more than causally inert aggregations of individuals. Methodological holism is the other traditional way of sociological thinking about the relationship between individuals and society. It insists that social structures definitely exist, i.e. have causal powers of their own, and that if anything it is people who are causally inert or close to inert; people's behaviour is determined by the pulls and pushes of structures (e.g. Althusser \& Balibar, 1970: 181). This perspective seems much more ambitious than the first one or even mystical. How can non-observable, supra-individual social entities exist and be causally active? Its appeal, however, lies in the intuitive notion that most of what people do, and the way they do it, in a society is very much influenced by 
impersonal forces beyond their control (such as, for example, the differential distribution of authoritative and allocative resources).

Many authors have pointed out the flaws in these two approaches; therefore I will not indulge myself. I will only note that for the past few decades many sociologists have consistently expressed the need to move beyond both methodological individualism and holism. Some have also poured much effort into devising an alternative approach to the issue. There is, for example, Anthony Giddens' structuration theory or Pierre Bourdieu's sociology of habitus and field. These are complex theories with many extremely useful insights as well as some pitfalls they can hardly be addressed properly in a short article such as this. However, I think we can say with certainty that these are not the most appropriate critical tools to be used as a means of infusing certain lost or dismissed humanist insights into contemporary "post-human" sociology, since Giddens' and Bourdieu's theories are themselves contributors to this orthodoxy. As Douglas Porpora recently states:

The Bourdieusian perspectives reflexive sociology, structuration theory, and practice theory are not anti-humanist in the sense of French post-structuralism, but do sometimes categorize themselves as post-humanist, likewise dismissing the conscious intentionality of the human actor. Practice and habitus stand in its place. (Porpora, 2015).

\section{Bringing the Subject Back in}

If (a critical reworking of) humanist Marxism has anything to contribute to contemporary sociology, as far as the relationship between structure and subject is concerned, it is just what tends to lack in theories such as Giddens' and Bourdieu's, not to mention Althusser's. The first such feature is what Porpora calls 'conscious intentionality of the human actor' and, we should add, related human abilities for reflexivity and forming new experiences. In short, we should reinstate the notion that people are relatively autonomous selves, irreducible self-aware agents with causal powers of their own. Anti-humanists have done away with all this and the various "post-humanists" have not really reinstated the notion. People are seen as guided primarily or even exclusively by unconscious dispositions (habitus), rules and routines. There is little sense of people as active, deliberate agents who themselves make their own relatively autonomous contributions to the social causal output. Take Laclau \& Mouffe, for example. They have been very vocal about the need to avoid Althusser's structural determinism; however, they themselves have reduced people to mere "'subject positions' within a discursive structure" (Laclau \& Mouffe, 2001). They go on to claim that human subjects are "not even ... endowed with powers that render an experience possible" (Ibid.). This is not a notion of the subject which accords it relative causal autonomy.

Giddens and Bourdieu would, of course, have none of this anti-humanist discursive reductionism but they do argue that human intentionality and reflexivity usually take a backseat in determining everyday social actions; unconscious routine 
and habitus take over instead. For Giddens (1984: 6) "much of our day to day conduct is not directly motivated", and even though subjects are "knowledgeable" (i.e. they are not Althusserian dupes), their knowledge consists of nothing more than what society offers. This means that in structuration theory "routine rules are ... what causally explain why actors behave as they do" (Porpora 1997: 251). Bourdieu's opinion is not all that different. For him habitus or, more precisely, "spontaneity without consciousness or will" (Bourdieu 1990: 56) is what primarily, if not exclusively, guides human behavior - this spontaneity itself the product of social structures called fields. Humanist talk of intentions, reasons, interests, reflexivity and conscious choices, however deeply situated in social contexts and influenced by them, reminds him too much of the apparently discredited rational choice theory (Bourdieu 1988). This is a mistake. We can and should appreciate the force of unconscious routine and habitus in determining people's actions without dismissing the (causal) importance of agents' intentionality, reflexivity and reasoning. Even Bourdieu himself admits this at certain points (e.g. Bourdieu and Wacquant 1992: 115; Bourdieu et al. 1999). (For critical accounts of Giddens see Archer 1995; Craib 1992; Creaven 2001; Cruickshank 2003; for nuanced critiques of Bourdieu see Archer 2010; Elder-Vass 2010b; Sayer 1999; Sayer 2010).

Before moving on to the second humanist feature I will argue for I should point out and address a possible objection to my claim that anti- and post-humanists usually downplay agency. For example, it could be argued that there are some contemporary post- structuralists, such as Jason Glynos and David Howarth (2007), who are largely influenced by Laclau, Foucault and other anti-humanists, who have recognized this problem and have tried to remedy it. Here is what Glynos and Howarth (2007) say:

We begin by accepting that social agents always find themselves "thrown into" a system of meaningful practices, an immersion that both shapes their identity and structures their practices. However, we also add the critical rider that these structures are ontologically incomplete. Indeed, it is in the "space" or "gap" of social structures, as they are rendered visible in moments of crisis and dislocation, that a political subject can emerge through particular "acts of identification".

So here we have "social agents" shaped by "a system of meaningful practices", i. e. structures, but not wholly determined by them. How is this room for human agency made possible? Although critical of the traditional humanist and hermeneutical accounts of the subject, as they "overemphasize the individual's creativity in coping with dilemmas", Glynos \& Howarth (2007:77) commit to a view which is not all that different from the one promoted in this article. They claim that subjects are not simply the result of power, discourse or other social forces by pointing out that people have an "ability 'to begin something new", a capacity for forming "dislocatory experiences ... to identify anew, and thus to act differently" (Glynos \& Howarth 2007:79). Later on they somewhat undermine this claim by saying that agents' psychology is not (even partially?) "a function of 'internal' states (beliefs, attitudes, predispositions, and so forth)" and that "inner mental processes" 
are (wholly?) "socially constructed" (Ibid.: 98). They also tilt back to the problematic Bourdieusian position when they emphasize that what people do are "largely repetitive activities that do not typically entail a strong notion of self-conscious reflexivity", activities "which have been inscribed on our bodies and ingrained in our human dispositions" (Ibid. 104; emphasis added). Still, they repeatedly claim that human agents are nevertheless inherently creative and never simply determined by their socially ingrained habitual responses. There is, therefore, an "inherent contingency that inhabits the social system", which can never be "banished once and for all" (Ibid, 104-105).

With this in mind it has to be accepted that there are theories claiming antihumanism as their ancestor but also arguing, at least in part, against its theoretical excesses. One can find this tendency in the works of some of post-human feminists and the so-called "new materialists" as well (e.g. Coole and Frost 2010; Braidotti 2013). My aim is not to dispute any of that, I only wish to add that the agential creativity and relative causal autonomy should be grounded with the help of cognitive and neuro-scientific accounts (for a thorough review see Bunge 2010; compare Kaidesoja 2013) and, therefore, with ample, even if not exclusive, references to human neurophysiology and biocultural evolution. If agential creativity is not so grounded, two things may take place instead. First, one can try to premise it more opaquely, speculatively and non-scientifically by, for example, constructing a strong "axiom ... of 'ontology of lack', which is a negative ontology premised on the radical contingency of social relations" (Glynos and Howarth, 2007: 14). Second, because such grounding does not locate intentionality and reflexivity in the human brain, it may also lead to an even more opaque post-humanist ontological schema, such as Jane Bennett's "enchanted materialism" or Bruno Latour's "actor-network theory". Here, any meaningful distinction between the intentional agency of humans and the much less exclusive, non-intentional agency of non-conscious matter collapses. I suggest both of those moves do more to undermine rather than buttress a serious effort to reemphasize human agency; a critical humanist perspective seems more apt.

So much for the first humanist feature I find useful. The second feature we should renew is the universalist notion that there are certain capabilities (and needs) which all human agents possess. One such capability is the already mentioned capacity for conscious intentionality and reasoned decision-making. This ability should not be seen as a gift from society, as structurationists argue (Archer 2000); they, contrary to anti-humanists, usually at least grant it existence even if they downplay its contribution to action. Instead, it should be seen as a universal part of humanity, a part of human nature. No doubt such humanist talk is frowned upon because of its "essentialist" overtones. Laclau and Mouffe (2001: 153), for example, insist that "the anthropological assumption of a "human nature'" is an "essentialist perspective" that needs to be rejected, and they are far from alone (e.g. Burr 2003). But there are good reasons, both empirical and conceptual, why such dismissals are wide off the mark (see Archer 2000; Bloch 2005; Chibber 2013; Creaven 2001; ElderVass 2012; Nussbaum 1992; Porpora 2015; Sayer 2011; Smith 2010). First of all, it is 
not clear how any sociological theory is even possible without some form of essentialism in general. Can we really analyse, say, the existing social system if we do not think there are certain essential, fundamental characteristics that make it capitalist and not, for example, feudal? If no social event, process, system or mechanism is determinate at least in some fundamental respects, as essentialism suggests, how could we theorize, categorize and compare anything? Secondly, essentialism about human nature in particular need not imply, as Laclau and Mouffe suggest, that there are no differences between individuals. There can be and, indeed, are large differences between people but this is not incompatible with the insistence that there nonetheless is a small core of features that are universal and transhistorical, e.g. the need for material well-being, the need for dignity and autonomy or the capacity for rational reflection. As Sayer (2011: 104) emphasizes:

To describe an object's essential properties ... does not mean that we cannot ac-knowledge that it also has other properties which may vary, perhaps significantly. Similarly, making claims about the particular capacities of human being does not mean that they are all manifested equally or in the same way everywhere ...

Essentialism and universalism are not the same thing as homogeneity. Essentialism and universalism recognize difference both in terms of what exists as well as how what exists is manifested. To give an example of the former, people sharing the same basic capacity for self-determination can at the same time have many other, vastly different capacities - some people are able to jump high, others are not, some can sing, others cannot. To give an example of the latter, people can satisfy their common need for food by eating a vast range of foods, prepared in a vast range of ways. The things people can eat, and the ways in which they can prepare those things for consumption, in order to satisfy their need for food are obviously not infinite, but they are not uniform either. Marx's (1990: 759) distinction between "human nature in general" and "human nature as historically modified in each epoch" is very useful here. The first refers to general, trans-historical needs and capacities people have in common, such as the need for food or shelter and the need for personal autonomy, while the latter refers to how these needs and capacities are expressed in a particular time and place in history.

Again it could be said that some post-marxists have recently recanted their earlier absolute rejection of all universal claims. Indeed, as Geoff Boucher (2008: 233) observes, "the leading theorists of post-marxism have discovered that without universality, there can be no resistance to domination". And in fact Laclau (2007: 26, 48) explicitly distances himself from any "appeal to pure particularism" and "a politics of pure difference". It is not possible, he notes, to do "away entirely with any kind of universal principle" because even the mere "assertion of one's own particularity requires the appeal of something transcending it" (Ibid.). More importantly, once we reject any kind of universal principle, it is no longer possible, Laclau now recognizes, to argue for universal human rights. This recognition is to be commended. However, Laclau still seems to me to be, owing to his poststructuralist 
scepticism of human nature, essences and the like, uneasy with universality. For instance, he writes of "relative universality" and emphasizes that his notion of universality "is very different from the universality which results from an underlying essence" (Laclau 2007: 54-55), for which I argue. But as I have noted above, the category of essences need not be problematic, especially if in its development we draw on contemporary concepts developed by scientific essentialists, for example Richard Boyd's concept of homeostatic property cluster kinds (Boyd 1991; Boyd 1999; see also Devitt 2008).

\section{Reconciling Structure and Subject Through Emergence}

How does this critical return to (Marxist) humanism not collapse into individualism, voluntarism, subjectivism of the old?4 In other words, are we not repeating the same Enlightenment mistakes that made humanism so vulnerable to current post-human orthodoxy? I claim we can avoid the collapse into traditional humanism if we make use of the ontological notion of emergence.5 Appreciating emergence allows us to bring in objective, unconscious, structural determinations of human actions without reducing the latter to the former. The notion of emergence is the idea that some things "can have properties or capabilities that are not possessed by its parts" (Elder-Vass 2010b: 5). The most common example of emergence is that of water, $\mathrm{H} 2 \mathrm{O}$. Water has certain causal powers which are lacking in both hydrogen as well as oxygen. It is only when these two elements are combined, organized in a certain way, that the causal power to extinguish a fire emerges. Before that hydrogen and oxygen only feed fires. "Similarly, water freezes at zero degrees centigrade, but hydrogen and oxygen would both be gases at this temperature. Water, then, has emergent properties" (Elder-Vass, 2010b: 5).

If we use the idea of emergence in the social realm, we can move beyond individual-ism and holism. Instead of either individuals making all the causal contributions to social dynamics, or social structures doing all the work, both can be seen as operative. In this case social structures should be seen as ontologically irreducible, causally active relations between individuals or, more precisely, between positions in which individuals are placed. These relations, e.g. the class relation between a capitalist and a worker or between a feudal lord and a peasant community, cannot exist or exert influence without their constituent parts, i.e. human individuals, but they possess causal powers above those possessed by these parts. This way we preserve both the subjective and the objective sociological domain. We have structures and subjects, objective positions and subjective experiences, background conditions and action.

Two further observations about the nature of structures qua relations are in order before moving on. Firstly, structures understood as relations between social positions should not be equated merely with shared rules or resources. Relations do, indeed, usually involve constitutive rules and resources but they are not exhausted by them. Let me give a Marxian example. It is not only because some people privately own certain resources, e.g. the means of production, that they possess and 
can exercise certain structural powers, e.g. the power to fire or exploit. The more important sociological fact is that some people own the means of production and that, for this very reason, the majority of people does not. This differential distribution of resources - an irreducibly relational fact - accounts for the (possible) occurrence of economic exploitation today. The relational fact that property-less workers are in an objectively vulnerable economic positions visa '-vis the capitalists ac-counts for the phenomenon of widespread extraction of surplus labour that goes on in the production process. I mention this partly because of the prevalent tendency in sociology to conflate structural relations with rules and resources (as such) and partly because of a particular critique of the Marxist treatment of structures. We can take Alexander Wendt's critique as a good example of both. He challenges Marxist talk of structures as somehow material or non-ideational by claiming that relations of production of which Marxists usually speak are, in fact, nothing of the sort. Quite the contrary, for him they are: thoroughly ideational phenomena, namely institutions and rules which are ultimately shared ideas that constitute property and exchange relationships, who works for whom, class powers and interests, and so on. The fact that relations of production are ideational means that capitalism is mostly a cultural form, not material, and as such Marxism's "material base" actually is shot through and through with ideas. (Wendt 1999: 94-5)

I say more on this below, but it should already be evident from the discussion above that such judgment is at least misleading if not mistaken. Social structures qua relations are not merely rules, i.e. shared ideas. They involve those, no doubt, and they also involve resources. But they nevertheless encompass more than simply that.

Secondly, and very closely related, we should, as Porpora insists (ironically, in the same paper Wendt explicitly draws upon), make a distinction between two types of social relations: "ideological" and "material" (Porpora 1993; 2015). This distinction goes back to Vladimir Lenin, who designated all those social relations "that are concept-dependent" as ideological, and all those that "are external and not similarly concept-dependent" as material (Porpora, 2015: 102). An example of the former is marriage, while the capitalist-worker relation is one of many examples of the latter. The difference between marriage and the capitalist-worker relation is that people cannot get married without understanding what they are doing, while they can be exploited without them being aware of it and without anybody conceptualizing it. Countering this by saying, as Wendt implies, that economic exploitation is actually an "ideological", not "material" relation because it is underpinned by legal rules of property ownership, which are most definitely ideational or concept-dependent in a direct and strong way, will not do. It will not do because exploitation is not the same as legal rules. Instead, it is an emergently objective, non-ideational property of such rules (Porpora 2015: 104). What is more, in the final analysis it is not even the formal possession by capitalists of resources, and the consequent legal exclusion of non-owners from access to them, which fundamentally underlies economic exploitation but their effective possession and non-owners' dispossession. This fact could continue to exist even in cases of legal 
change. Capitalists could, given their effective possession of resources and the effective dispossession of resources by workers, muster the repressive force needed to maintain such differential distribution even in the absence of a legal system stipulating private ownership. This is not a very stable social state, especially not in the long run, but it is certainly possible.

To illustrate the proposed reconciliation between structure and subject, let us look now more closely at class relations in capitalism. Why do capitalists compete on the market by maximizing profits? Why do workers seek jobs and even offer themselves up for exploitative employment; why do they compete with their fellow workers for jobs? I suggest it is not because they are somehow unconsciously obliged to follow social rules or their habitus, neither is it because they are trans-historically and individually wired to act in capitalist ways.

It is in virtue of the reciprocal influence on their behaviour of both objective structural relations they are embedded in and the needs, interests and capabilities they possess as members of the human species. Let us turn to capitalists first. They are placed in competitive market relations with other capitalists so that if they do not maximize profits they are faced with the likely chance of going bankrupt or being taken-over by competitors. Put simply, if they do not act in the usual capitalist manner, they risk the deprivation of their need for material well-being and autonomy. Workers, likewise, seek employment - even exploitative employment primarily because they know, or soon find out, what would happen otherwise. Given their objective location in the network of class relations - i.e. given that they are property-less and that they do not have direct, non-market access to the means of subsistence they would risk their most fundamental human needs going unsatisfied by refusing to seek employment (or by not competing against other workers). So, in the case of capitalists and workers it is both their structural location and their individual needs along with conscious choice that produce the common competitive capitalist behaviour we often observe in capitalism. The connection between structure and subject runs via the categories of objective relations, interests, subjective experiences, intentionality and, finally, motivated action (see, for more on this, Archer, 1995; Creaven, 2001; 2015; Porpora, 1989).

(The same case, mutatis mutandis, can be made for pre-capitalist class societies. Robert Brenner's (1985: 236-242) notion of "political accumulation" carried out by pre-capitalist lords, and the related notion of "safety-first" production carried out by pre-capitalist peas-ants, elegantly marries structure and subject, objective class relations and subjective, consciously motivated actions. It is precisely in virtue of human needs that these pre-capitalist actors have and in virtue of feudal class relations between them (i.e. relations within the lordly class, and relations between lords and peasants) that endemic warfare, geopolitical expansion, monarchical centralization, extra-economic exploitation and non-specialized, i.e. diversified, agrarian production exhibiting Malthusian characteristics usually prevailed.)

This might seem like a return to structuralism and holism. Am I suggesting that social structures compel people to act in certain ways? No. First of all, because 
people have the natural capacity for conscious intentionality, reflexivity and choice they can always and everywhere refuse to act in ways to which their structural locations point. Secondly, even when people choose to go along with the structurally "prescribed" way, they do not do so solely because of structural forces, nor is it mysterious why they do as they do. As I have said, structures simply put people in certain life situations, which they then usually consciously experience and which bring certain opportunity costs (defined in a broad, non-economistic manner) that are also usually perceived. Since they are positioned on different locations within social relations, people are objectively faced with different opportunities, strategies and ways to satisfy their human needs and interests. Workers, in virtue of being in the position of workers and in virtue of being human persons, will face serious difficulties if they do not get a job. It will be hard for them to even survive, let alone live. Capitalists, in virtue of being in the position of capitalists and in virtue of being human persons, will face serious difficulties if they do not maximize profits. They will lose their comfortable class situation, which accords them lots of material wellbeing, autonomy, and so on, and will join the ranks of workers. People, most of the time, choose to act in ways broadly compatible with their structural location not because they are somehow forced to do so, not because they are nothing but Althusserian Träger, but simply because it is too costly not to do so. It is for this reason, after all, (and because the appropriate means are usually lacking) that structural change is no easy task and does not happen most of the time. And it is for this reason that capitalists and workers everywhere, no matter their specific culture, strive for profits, compete with one another and seek jobs.

\section{Scientific Explanation or Ethical Critique?}

There is a tendency, both within and outside Marxism, to set "hard" science in a zero-sum relationship to "humanist" ethics. A related, yet distinct dilemma with value judgements was present in the works of Marx himself. He denounced value judgements as bourgeois ideology and at the same time charged capitalist exploitation with all manners of immorality and degradation (Geras, 1985; 1992). In sociology, more generally, it is perhaps Max Weber who is most famous for his insistence that proper social science should not concern itself with espousing value judgements. He says:

Suppose that Tolstoy rises up in you once more and asks, "who if not science will answer the question: what then shall we do and how shall we organize our lives?" Or, to put it in the language we have been using here: "Which of the warring gods shall we serve? Or shall we serve a completely different one, and who might that be?" In that event, we must reply: only a prophet or a saviour (Weber, 2004:2728)

And again:

Only on the assumption of belief in the validity of values is the attempt to espouse value-judgements meaningful. However, to judge the validity of such values is a matter of faith. It may perhaps be a task for the speculative interpretation 
of life and the universe in the quest of their meaning. But it certainly does not fall within the province of an empirical science in the sense in which it is to be practised here (Weber, 1949: 55).

If this is true, a few problems arise. First of all, how can humanist Marxism contribute to the scientific project of contemporary sociology, given that it carries with it all sorts of explicit and implicit moral claims? On the one hand, humanist Marxism is full of moral condemnations of capitalist exploitation, neoliberal structural reforms or the oppression of women and minorities. It claims all this degrades, mutilates and stifles human life so it should be done away with. On the other hand, it incessantly promotes progressive practices and ideas, which, ostensibly, contribute to the good life, i.e. to human flourishing. If sociology is to be a Weberian value-free science it cannot taint itself with such judgements. Secondly, however, how appealing is it really to strive to rid sociology (whether inspired by Marxism or not) of its value judgments today, in the midst of the largest capitalist crisis since the Great Depression and the rise of extreme-right populist forces all across Europe and the US? There is so much human suffering in the world and it seems simply insidious to claim sociology should be neutral in relation to it, either by refusing to take any stand on it or by affirming the Weberian view that sociologist's moral views (concerning, perhaps, violence against refugees) are a matter of faith. Should we not, as Stevenson (2016: 5) puts it, now more than ever "place moral questions at the centre of the [sociological] argument rather than at the periphery"? I suggest we tackle these issues by briefly examining how wide the gap between facts and values to which Weber alludes really is.

To begin with, it should be obvious that such a gap or distinction really exists. There is no going back to strong moral realism or ethical naturalism (Elder-Vass 2010) which strives to derive values directly from facts or which collapses any distinction between them. On this, David Hume was correct. Therefore, we must begin any moral argument not from matters of fact but from moral or ethical premises. One such premise is that human flourishing is good, while human suffering is bad - or, that we should value all humans. There can be no fundamental, matter-of-fact justification for this premise. However, if we take it on board - and it seems pretty unreasonable not to do so - we can, at the very next step of the argument, bring in facts. If it is true, as I argued in the previous section, that human persons are not simply social constructs, determined from top to bottom by various social forces, such as discourse, ideology, structures etc., then there are various universal needs, capabilities and interests all people share simply in virtue of being human. Every person has, as a consequence of their bodily and brain biology, a need for material well-being (i.e. for shelter, food and water, absence of chronic pain etc.) or a need for autonomy and dignity, for identity and recognition. This holds true irrespective of the particular culture into which a person is embedded.

Of course, the ways in which these needs are expressed vary across cultures and are manifold. But because some human needs are universal and because they are not simply the completely malleable product of the socio-cultural context in 
which an individual lives, there is a possibility of certain contexts or, more precisely, certain socio-cultural practices to come into conflict with people's fundamental needs. Not just any form of socio-cultural expression is adequate or equally adequate for human flourishing, although many are. To give just the most obvious example, people cannot survive on a diet of sand or a diet of 200 kilocalories of potatoes per day. No culture can change that, even if it tries. Go-ing beyond bare survival, people definitely can survive while being denied their human need for autonomy, if they are kept as slaves (as long as they have food and similar bare necessities), but they cannot flourish as such slaves, who are, for example, kept in tight cages most of the day. Their autonomy, dignity, the capacity for creativity etc. are being completely or almost completely denied in such a context. The same goes for less extreme, yet still utterly deplorable examples such as the oppression and bodily mutilation of women and minorities, exploitation of workers, human trafficking, violence towards refugees etc.

All these practices frustrate fundamental human needs and capacities and, by doing so, promote suffering and stifle human flourishing. It is hard to come to a wide-spread agreement on a detailed list of what constitutes fundamental human needs and capacities which should be respected everywhere. It is even harder to move from such moral considerations to action that is needed to ameliorate existing human suffering defined as the denial of basic humanity. But the point here is just that humanist moral considerations (in sociology and elsewhere) need not be wholly extra-scientific, unconcerned with facts. They are not in a zero-sum relationship with scientific concerns. This is important because it gives moral critique stronger justification. Moral critique is not mere opinion or faith, which can be dismissed out of hand:

The capabilities approach is important not just because it shows how discourse ethics can proceed from very basic value claims like 'value all humans' to more substantive moral claims, but also because these are moral claims that we can measure the real social world against. When organisations, institutions, policies and people fail to deliver or protect these central capabilities, we have a case for criticising them. (Elder-Vass 2010a: 55).

Bridging the gap between facts and values in the manner indicated is, as Reha Kadakal (2013: 592) puts it, "an undertaking [that is] long overdue in sociology as a discipline" (see also Gorski, 2013). It offers us two things. First, it enables us to circumvent Weber's (2004:21) popular argument that "whenever an academic introduces his own value judgement, a complete understanding of the facts comes to an end". In fact, the reverse seems to be true. For example, when Marx analyses the capitalist-worker relation in Volume 1 of Capital and identifies it as nothing less but an exploitative relationship which involves robbery, despotism and bodily mutilation, this should be seen as enriching our "understanding of the facts", not diminishing it. It would be an imperfect, incomplete understanding of the facts if, in the case that the capitalist-worker relationship really is exploitative and really has the alleged effects on the human body and psyche, we left this "moral fact" out. 
Secondly, bridging the gap between facts and values in the way I have suggested enables us to avoid the dead-end of moral relativism (either within cultures or between them). Such relativism posits, in the words of one of its representatives, that there "are no objectively-based universal standards by which to judge right and wrong" at least between different cultures (Feinberg, 2011:517). This is rarely defended so explicitly but it is hard to see how moral relativism is not necessarily implicit in every theory which embraces the radical discontinuity between facts and values, and which denies the existence of trans-cultural human nature. If there is no connection between facts and values, then Weber is right and we only have faith when it comes to morality. And even if it is admitted that a connection exists, moral relativism is still possible in case people are simply the products of their specific cultural locations. If there are no fundamental, universal human needs and capacities and, instead, people are simply what their cultures make them out to be, then any cultural practice is legitimate (as long as it is the one that constructed the individual in question). Society and culture cannot harm people if they wholly coincide, i.e. if the latter are perfect copies of the former.

\section{CONCLUSION}

The "post human orthodoxy that is still prevalent in the humanities and social sciences" (Chernilo 2016:310) should engage with a critical, Marxist humanism, which offers the possibility of resolving many dilemmas that plague the disciplines in question. In this article, I have suggested how it does so with regards to the tortured relationship between society and the individual, structure and subject or the objective and the subjective, as well as the relationship between facts and values.

As far as the first task goes I have argued that in order to non-reductively connect the objective (structures) with the subjective (subjects) it is required of us to investigate the causal chain between objective relational positions, interests, subjective experiences and motivated actions of people. This causal chain is not a one-way street nor does it operate in a positivist, determinist fashion. As Marx (1978: 595) states, people, not structures, "make their own history". However, it still holds that "they do not make it just as they please; they do not make it under circumstances chosen by themselves". This means it is both structures (as objective relations) as well as needy self-aware subjects that contribute to the causal output in society. Neither is reducible to the other, nor are they reducible to some third thing, for example practice, habitus or rules. As far as the second task goes, bridging the gap between facts and values with the aid of a rich and non-reductive concept of human nature (such as on offer by Nussbaum 1992 or Sayer 2011) promises to simultaneously counter both "positivist scientism" as well as "the discourses of cultural and moral relativism" (Kadakal 2013: 592). This is no naïve moral realism or strong ethical naturalism which strives to derive values strictly and directly from states of affairs. It is a highly qualified, weak ethical naturalism (Sayer 2005; ElderVass 2010a) which starts from irreducible moral premises, for instance the premise that we should value all humans and that we should promote human flourishing. 
Only then does it turn to facts, i.e. facts about what actually constitutes human flourishing.

\section{REFERENCES}

1. Althusser, L., \& Balibar, É. (1970). Reading Capital. London: Verso.

2. Archer, M. S. (1995). Realist Social Theory: The Morphogenetic Approach. Cambridge: Cambridge University Press.

3. Archer, M. S. (2000). Being Human. Cambridge: Cambridge University Press.

4. Archer, M. S. (2010). Can Reflexivity and Habitus Work in Tandem? In: M. Archer. (ed.): Conversations about Reflexivity: 123-143. London: Routledge.

5. Benton, T. (1984): The Rise and Fall of Structural Marxism: Althusser and His Influence. New York: St. Martin's Press.

6. Bloch, M. (2005). Essays on Cultural Transmission. Oxford: Berg.

7. Boucher, G. (2008): The Charmed Circle of Ideology: A Critique of Laclau \& Mouffe, Butler \& Žižek. Melbourne: Repress.

8. Bourdieu, P. (1990). The Logic of Practice. California: Stanford University Press.

9. Bourdieu, P., et al. (1990):.The Weight of the World: Social Suffering in Contemporary Society. Cambridge: Polity Press

10. Bourdieu, P., \& Wacquant, L. (1992). Invitation to a Reflexive Sociology. Chicago: University of Chicago Press.

11. Boyd, R. (1991). Realism, Anti-Foundationalism and the Enthusiasm for Natural Kinds. Philosophical Studies, 61: 127-148.

12. Boyd, R. (1999). Homeostasis, Species, and Higher Taxa. In: R. A. Wilson (ed.): Species 141-185. Cambridge: MIT Press.

13. Braidotti, R. (2013). The Post-human. Cambridge: Polity Press.

14. Brenner, R. (1985): The Agrarian Roots of European Capitalism. Cambridge: Cambridge University Press.

15. Brereton, D. (2011). Requiem for Relativism in Anthropology. Journal of Critical Realism, 10 (3): 358-391.

16. Bunge, M. (2010). Mind and Matter. A Philosophical Inquiry. London: Springer.

17. Burr, V. (2003). Social Constructionism. London: Routledge.

18. Carling, A. (1986): Rational Choice Marxism. New Left Review, I (160): 24-62.

19. Chernilo, D. (2016): Review Essay: Humanism and Sociology. Journal of Classical Sociology, 16 (3): 310-317.

20. Chibber, V. (2006). On the Decline of Class Analysis in South Asian Studies. Critical Asian Studies, 38 (4): 357-387.

21. Chibber, V. (2013). Postcolonial Theory and the Specter of Capital. London: Verso.

22. Collins, R. (1981). On the Micro foundations of Macrosociology. American Journal of Sociology, 86 (5): 984-1014.

23. Coole, D., \& Frost, S. (2010). Introducing the New Materialisms. In: D. Coole and S. Frost (eds.): New Materialisms. Ontology, Agency, and Politics, 1-46. Durham: Duke University Press.

24. Craib, I. (1992). Anthony Giddens. London: Routledge. 
25. Creaven, S. (2001). Marxism and Realism. A Materialistic Application of Realism in the Social Sciences. London: Routledge.

26. Creaven, S. (2015). The 'Two Marxisms' Revisited: Humanism, Structuralism and Realism in Marxist Social Theory. Journal of Critical Realism, 14 (1): 7-53.

27. Cruickshank, J. (2003). Realism and Sociology. Anti-foundationalism, Ontology and Social Research. London: Routledge.

28. Devitt, M. (2008). Resurrecting Biological Essentialism. Philosophy of Science, 75 : 344-382.

29. Durkin, K. (2014). The Radical Humanism of Erich Fromm. New York: Palgrave Macmillan.

30. Elder-Vass, D. (2010a). Realist Critique without Ethical Naturalism and Moral Realism. Journal of Critical Realism, 9 (1): 33-58.

31. Elder-Vass, D. (2010b). The Causal Power of Social Structures. Emergence, Structure and Agency. New York: Cambridge University Press.

32. Elder-Vass, D. (2012). The Reality of Social Construction. Cambridge: Cambridge University Press.

33. Elder-Vass, D. (2014). Social Entities and the Basis of Their Powers. London: Springer.

34. Eley, G. (2005). A Crooked Line: From Cultural History to the History of Society. Ann Arbor: University of Michigan Press

35. Elster, J. (1985). Making Sense of Marx. Cambridge: Cambridge University Press.

36. Elster, J. (1986). An Introduction to Karl Marx. Cambridge: Cambridge University Press.

37. Feinberg, R. (2011). Much Ado About Very Little. Journal of Critical Realism, 10 (4): 511-519.

38. Geras, Norman (1985). The Controversy about Marx and Justice. New Left Review, I (150): 47-85.

39. Geras, N. (1992). Bringing Marx to Justice: An Addendum and Rejoinder. New Left Review, I (195): 37-69.

40. Giddens, A. (1984). The Constitution of Society. Berkeley: University of California Press.

41. Glynos, J., \& Howarth, D. (2007). Logics of Critical Explanation in Social and Political Theory. London: Routledge.

42. Gorski, P. (2013). Beyond the Fact/Value Distinction: Ethical Naturalism and the Social Sciences. Society, 50 (6): 543-553.

43. Gouldner, A. (1980). The Two Marxisms. Contradictions and Anomalies in the Development of Theory. New York: Oxford University Press.

44. Hall, S. (1982). Cultural Studies: Two Paradigms. Media, Culture and Society 2: 5772.

45. Hall, S. (1985): Signification, Representation, Ideology: Althusser and the PostStructuralist Debates. Critical Studies in Mass Communication, 2 (2): 91-114. 
46. Hall, S. (1988). The Toad in the Garden: Thatcherism among the Theorists. In: C. Nelson and L. Grossberg (eds.): Marxism and the Interpretation of Culture: 3574. Chicago: University of Illinois Press.

47. Hall, S. (1996): Who Needs 'Identity'? In: S. Hall and P. du Gay (eds.): Questions of Cultural Identity: 1-17. London: Sage Publications.

48. Kadakal, R. (2013). Truth, Fact and Value: Recovering Normative Foundations for Sociology. Society, 50 (6): 592-597.

49. Kaidesoja, T. (2013). Naturalizing Critical Realist Social Ontology. London: Routledge.

50. Kim, J. (1999). Making Sense of Emergence. Philosophical Studies, 95: 3-36.

51. Laclau, E. (2007). Emancipation(s). London: Verso.

52. Laclau, E., \& Chantal, M. (2001). Hegemony and Socialist Strategy: Towards a Radical Democratic Politics. London: Verso.

53. Maher, S. (2016). Escaping Structuralism's Legacy: The Renewal of Theory and History in Historical Materialism. Science \& Society, 80 (3): 291-318.

54. Marx, K. (1978). Brumaire the Eighteenth of Louis Bonaparte. In: R. Tucker (ed.): The Marx-Engels Reader: 594-617. New York: W. W. Norton.

55. Marx, K. (1990). Capital. A Critique of Political Economy. Volume One. London: Penguin Books.

56. Nussbaum, M. (1992). Human Functioning and Social Justice: In Defense of Aristotelian Essentialism. Political Theory, 20 (2): 202-246.

57. Porpora, D. (1989). Four Concepts of Social Structure. Journal for the Theory of Social Behaviour, 19 (2): 195-211.

58. Porpora, D. (1993). Cultural Rules and Material Relations. Sociological Theory, 11 (2): 212-229.

59. Porpora, D. (1997). The Caterpillar's Question: Contesting Anti-Humanism's Contestations. Journal for the Theory of Social Behaviour, 24 (2-3): 243-263.

60. Porpora, D. (2015). Reconstructing Sociology: The Critical Realist Approach. Cambridge: Cambridge University Press.

61. Sayer, A. (1999). Bourdieu, Smith and Disinterested Judgement. The Sociological Review, 47 (3): 403-431.

62. Sayer, A. (2005). The Moral Significance of Class. Cambridge: Cambridge University Press.

63. Sayer, A. (2010). Reflexivity and Habitus. In: M. Archer (ed.): Conversations about Reflexivity: 108-122. London: Routledge.

64. Sayer, A. (2011). Why Things Matter to People. Social Science, Values and Ethical Life. Cambridge: Cambridge University Press.

65. Smith, C. (2010). What is a Person? Rethinking Humanity, Social Life, and the Moral Good from the Person Up. Chicago: University of Chicago Press.

66. Stevenson, N. (2016). E. P. Thompson and Cultural Sociology: Questions of Poetics, Capitalism and the Commons. Cultural Sociology, Online-first, 1-17.

67. Weber, M. (1949). The Methodology of the Social Sciences. Illinois: The Free Press. 
68. Weber, M. (2004). Science as a Vocation. In: D. Owen and T. B. Strong (eds.): Max Weber. The Vocation Lectures: 1-31. Cambridge: Hackett Publishing Company.

69. Wendt, A. (1999). Social Theory of International Politics. Cambridge: Cambridge University Press.

70. Wimsatt, W. C. (2000). Emergence as Non Aggregativity and the Biases of Reductionism. Foundations of Science, 5: 269-297.

71. Wood, E. M. (1995). Democracy against Capitalism. Renewing Historical Materialism. Cambridge: Cambridge University Press. 